\title{
INMIGRACIÓN Y MEMORIA SOCIAL EN BERISSO (ARGENTINA). UN ANÁLISIS DE LOS LUGARES DE MEMORIA, LAS PRÁCTICAS CONMEMORATIVAS Y LOS OBJETOS LIGADOS A LA INMIGRACIÓN ULTRAMARINA

\author{
Immigration and Social Memory in Berisso (Argentina). \\ An analysis of the sites of memory, commemorative practices \\ and the objects linked to overseas immigration
}

\author{
Nicolas Herrera*1 \\ CONICET y Universidad Nacional de La Plata (Argentina)
}

Palabras clave

Inmigración

Memoria social

Argentina

Keywords

Immigration

Social memory

Argentina

\begin{abstract}
RESUMEN: El artículo analiza - a escala local- el proceso de espacialización, materialización y transmisión de uno de los ejes que estructuran la memoria oficial de la Argentina: la llegada de inmigrantes ultramarinos durante el periodo de entre siglos $(x \mid x-x x)$ y el rol jugado por dichos actores en la conformación poblacional de un armónico crisol de razas. A partir de la descripción de tres lugares de memoria emplazados en la ciudad de Berisso, las prácticas conmemorativas que se desarrollan en ellos y los objetos materiales investidos de sentidos memoriales que alli se exhiben, mostramos la capacidad que han tenido distintos actores de la sociedad civil (las asociaciones étnicas locales) y del Estado (la intendencia municipal) para instituir a los inmigrantes ultramarinos en figuras míticas de la memoria local/nacional: héroes, pioneros y padres fundadores de la comunidad. Este proceso no solo relega a un lugar marginal a otros actores presentes en la historia de la ciudad/nación (inmigrantes limítrofes, migrantes internos) sino que, además, silencia/olvida cualquier indicio de conflictividad que pudiera haber existido durante el proceso de integración de los inmigrantes ultramarinos con la sociedad berissense/argentina. Así, a partir del material elaborado durante un extenso trabajo de campo de tipo cualitativo, el artículo muestra que la figura legitimada en los lugares de memoria, en las prácticas conmemorativas y en los objetos analizados no es la de cualquier inmigrante, sino la del inmigrante ultramarino, exitosamente integrado a la cultura nativa y respetuoso de las instituciones locales.
\end{abstract}

ABSTRACT: The article analyzes - at a local level- the process of spatialization, materialization and transmission of one of the core ideas that shape the official memory of Argentina: overseas immigrants' arrival during the period between 19th and 20th centuries and the role played by those actors in the population configuration of a harmonious crisol de razas. Based on the description of three sites of memory located in the city of Berisso, the commemorative practices developed and the material objects vested with memorial senses exhibited, we show the capacity that different civil society actors (local ethnic associations) and the State (the municipality) have had to establish the overseas immigrants as mythical figures of the local/national memory: heroes, pioneers and founding fathers of the community. Not only does this process relegate other actors present in the history of the city/nation (bordering immigrants, internal migrants) to a marginal place but it also silences/forgets any sign of conflict that could have occurred during the integration process of overseas immigrants with the society from Berisso/Argentina. Thus, based on the material elaborated during extensive qualitative fieldwork, the article shows that the legitimized figure in the sites of memory, in the commemorative practices and the analyzed objects is not any immigrant's figure, but that of the overseas immigrant, successfully integrated with the native culture and respectful of local institutions.

1 Becario de la Fundación Carolina (España), 2021.

* Correspondencia a / Correspondence to: Nicolas Herrera. Universidad Nacional de La Plata, Facultad de Humanidades y Ciencias de la Educación, calle 51 e/ 124 y 125, (1925) Ensenada (Buenos Aires, Argentina) - herreranicolas@hotmail.com - http://orcid.org/0000-0002-0451-4813.

Cómo citar / How to cite: Herrera, Nicolas (2021). «Inmigración y memoria social en Berisso (Argentina). Un análisis de los lugares de memoria, las prácticas conmemorativas y los objetos ligados a la inmigración ultramarina». Papeles del CEIC, vol. 2021/1, papel 247, 1-21. (http://dx.doi.org/10.1387/pceic.22207).

Fecha de recepción: noviembre, 2020 / Fecha aceptación: enero, 2021.

ISSN 1695-6494 / CC 2021 UPV/EHU 
Como parte de la proliferación de estudios sobre el pasado reciente (Franco y Levín, 2007), algunos científicos sociales afirmaron que nuestra contemporaneidad debería ser definida como una era de las conmemoraciones (o una era del testigo) donde la pasión archivística, la obsesión, el exceso, la sobreabundancia o el abuso de la memoria se ha vuelto moneda corriente (Nora, 2008; Maier, 1993; Wieviorka, 1998; Todorov, 2000; Eiss, 2002). Este boom o cultura de la memoria (Huyssen, 2001), surgido en las sociedades occidentales durante la década de 1980, fue una de las reacciones generadas ante la posibilidad de que ciertos hechos violentos, doloroso o traumáticos del pasado reciente fueran silenciados u olvidados: centralmente, los crímenes cometidos durante la Segunda Guerra Mundial y el nazismo.

Pese al creciente interés por los usos sociales del pasado y la construcción de memorias colectivas, estas temáticas poseen un lugar marginal y un desarrollo reciente dentro del campo de los estudios migratorios, tanto en los Estados Unidos y Europa (Huyssen, 2003; König y Ohliger, 2006; Glynn y Kleist, 2012, 2015; Tošić y Palmberger, 2016) como en la Argentina (GEMAS, 2016; Herrera y Monkevicius, 2019). Este artículo se sitúa en esa intersección novedosa y poco explorada, conformada por el cruce entre el campo de los estudios migratorios y el campo de estudios de la memoria social, para analizar la espacialización, materialización y transmisión de uno de los ejes que estructuran la memoria oficial de Berisso ${ }^{2}$ y la Argentina. Ese eje se encuentra ligado a la llegada de inmigrantes ultramarinos durante el período de entre siglos $(X I X-X X)$ y su rol en la conformación poblacional de un armónico crisol de razas ${ }^{3}$.

Este tema será abordado a partir del análisis de tres lugares de memoria (Nora, 2008), las prácticas conmemorativas que se desarrollan en ellos (Connerton, 1993; Olick, 2003; Pollak, 2006) y los objetos materiales investidos de sentidos memoriales que allí se exhiben (Bustamante, 2016; Bjerg, 2019). El Parque Cívico, la Curva de las Naciones y el Museo 1871 son lugares en (y a partir de) los cuales las asociaciones étnicas locales y la intendencia municipal han logrado espacializar, materializar y transmitir dicho eje de la memoria oficial, trayendo al presente un pasado mítico de la comunidad. Lugares donde se desarrollan diversos rituales conmemorativos que reciben su reconocimiento por la sanción aprobatoria del Estado (Jelin y Langland, 2003). En suma, analizamos una serie de prácticas a través de las cuales dichos actores han espacializado, materializado y transmitido una memoria oficial que, lejos de estar relacionada con los crimenes cometidos por gobiernos dictatoriales, está vinculada a la construcción de las naciones moderas (Nora, 2008; Gillis, 1994).

El artículo está dividido en dos grandes apartados. En el primero presentamos un sucinto recorrido por la historia inmigratoria, fabril y política de Berisso. En el segundo mostramos cómo las asociaciones étnicas locales y la intendencia municipal han logrado materializar, espacializar y transmitir una memoria oficial sobre dichos procesos, haciendo énfasis en las for-

2 Ubicada en la Provincia de Buenos Aires, a 9 km de La Plata (capital de la provincia), linda con el Rio de la Plata y posee una población de 88.123 personas (INDEC, 2010).

3 El concepto de crisol de razas presenta similitudes con los de melting pot (estadounidense), creuset (francés) y candinho das razas (brasilero). Sin embargo, ellos explican procesos de construcción de etnicidad y acceso a la ciudadanía que responden a marcos nacionales completamente distintos. Y, por lo tanto, no deberían ser homologados o traducidos de manera directa (Segato, 2007). En líneas generales, el concepto de crisol de razas fue utilizado para explicar el proceso a través del cual el Estado Nación argentino buscó fusionar la heterogeneidad cultural de su población en una etnicidad tan ficticia como homogénea, tan blanca como de origen europeo. Este concepto presupone un proceso armónico de integración de los inmigrantes a la sociedad argentina. Inmigrantes que abrían fundido sus pautas culturales sin conflictos, dando lugar a una nueva etnicidad, la argentina. 
mas a través de las cuales se recuerda el pasado inmigratorio de la ciudad, en los tres lugares de memoria mencionados anteriormente. El artículo se cierra con una serie de reflexiones que dan cuenta de la centralidad que ocupa la inmigración ultramarina dentro de la memoria oficial de la comunidad. Allí se señala el carácter edulcorado, a-conflictivo y unificador que poseen los recuerdos que, sobre dichos actores, se materializan y transmiten en la escena pública. Metodológicamente el artículo está sostenido por los registros elaborados durante un extenso trabajo de campo de tipo etnográfico ${ }^{4}$, en el cual las observaciones participantes y el trabajo de archivo ocupó un lugar central: el Museo 1871.

\section{BERISSO: MIGRACIÓN, TRABAJO Y POLITIICA}

Entre fines del siglo xIx y principios del siglo xx Berisso se desarrolló como resultado del cruce entre su localización portuaria y la instalación de un extendido sistema fabril. Este cruce tuvo tanto peso en la conformación de la ciudad que su nombre fue adoptado en honor a Juan Berisso, empresario italiano que puso en funcionamiento el primer saladero ${ }^{5}$ de la ciudad (1871). La instalación del saladero San Juan inauguró un tejido industrial que se extendió durante el primer cuarto del siglo xx con la apertura de tres frigoríficos, una destilería de crudo y una hilandería: La Plata Cold Storage (1904), Swift (1907), Armour (1915), Yacimientos Petrolíferos Fiscales (1925) y The Patent Knitting Company (1926) (Lobato, 2004; Muñiz Terra, 2012).

La ubicación portuaria y la expansiva oferta de trabajo fueron factores decisivos para que esta ciudad se convierta en uno de los destinos del flujo inmigratorio que, masivamente, llegó a la Argentina entre fines del siglo xIX y principios del siglo xx: en 1914 el 59\% de su población era extranjera (Lobato, 2004; De Cristóforis, 2016). La mayoría de esos inmigrantes llegaban desde Italia y España, aunque era notoria la presencia de personas provenientes de Bielorrusia, Ucrania, Siria, Palestina, Líbano, Jordania, Polonia, Checoslovaquia, Bulgaria, Grecia, Lituania y Serbia.

Para enfrentar la heterogeneidad étnica existente en la ciudad, crear hospitales donde asistir a sus connacionales, editar periódicos que los mantuvieran informados, cubrir gastos de sepelios, ayudar a los recién llegados en la búsqueda laboral, brindar seguros de desempleo, pagar los gastos de repatriación y, fundamentalmente, conformar un ámbito de sociabilidad que permitiera reproducir las pautas culturales de sus países de origen, aquellos inmigrantes conformaron un extenso tejido de asociaciones étnicas que los agrupó por nacionalidad, lengua y costumbres compartidas: en menos de treinta años (1907-1934) los inmigrantes que vivían en Berisso crearon un total de veinticuatro asociaciones étnicas (Herrera, 2018).

Si hasta mediados de la década de 1930 las identificaciones étnicas vincularon a los actores con mayor capacidad que las identificaciones políticas y las de clase, los conflictos laborales desatados a partir de esa fecha hicieron que las diferencias idiomáticas, culturales y nacionales comenzaran a quedar relegadas frente una condición compartida: ser trabajadores. Esta situación se dio en un contexto donde la población de Berisso aumentó considerable-

\footnotetext{
4 Este artículo ha sido escrito a partir de algunos registros elaborados para mi tesis doctoral (Herrera, 2018) durante el período 2010-2015 y otros elaborados específicamente durante el período 2019-2020.

5 Establecimiento donde se producía carne salada, seca y cocida para exportación.
} 
mente, siendo la población nativa la que creció de manera exponencial. Si bien entre 1914 y 1947 el número de extranjeros radicados en Berisso continuó aumentando (pasando de 5.243 a 9.853), entre 1947 y 1960 descendería hasta llegar a las 7.508 personas. Frente a la población de origen extranjero, la población nativa pasó de estar compuesta por 3.604 personas en 1914 a 24.117 en 1947 y 33.475 en 1960; haciendo que la participación de los extranjeros sobre la población total de la ciudad disminuyera desde un 59\% (1914), al 29\% (1947) y, finalmente, al 18\% (1960) (Lobato, 2004). Frente a estos datos cuantitativos, el carácter cualitativo del aumento de la población nativa radicada en Berisso se volvería sumamente importante: dicho aumento no solo se debió al nacimiento de las primeras generaciones de argentinos con padres inmigrantes sino, fundamentalmente, a la migración interna de argentinos provenientes de Santiago del Estero, Corrientes, Tucumán y Catamarca que llegaron a Berisso a fines de la década de 1930 buscando trabajo (James, 2004; Lobato, 2004).

La conflictividad laboral y el marcado descenso en la proporción de inmigrantes sobre la población total confluyeron para que a mediados del siglo xx los trabajadores insertos en la extensa trama fabril de la ciudad encontraran en la articulación política un camino para identificar los problemas que atravesaban las diferencias étnico-nacionales. En este contexto, las fronteras de pertenencia no solo se volvieron más restringidas (pasando de la fragmentación y la heterogeneidad étnica a la articulación y la homogeneidad laboral) sino que comenzaron a estar nucleadas por distintas adscripciones políticas: a las agrupaciones anarquistas, socialistas y comunistas se les sumaron la Unión Cívica Radical y el sindicalismo fabril.

En el marco de estas dinámicas, entre mediados de 1944 y fines de 1945 Berisso atravesó un período que con el correr de los años se volvería crucial en la reconstrucción de un imaginario local y sus prácticas conmemorativas: su vínculo con los orígenes del peronismo. Durante los primeros días de agosto de 1944 Juan Domingo Perón llegó a la ciudad para visitar el Sindicato Autónomo de la Carne y anunciar la construcción de viviendas para los trabajadores del sector 6 . Alli se le informó sobre la situación de 150 empleados recientemente despedidos, ante quienes Perón se comprometió a lograr su reincorporación. Días después Perón regresó a Berisso para ser homenajeado en una jornada donde los obreros colmaron el acto y los frigoríficos quedaron vacíos. Sin embargo, entre 1944 y 1945 esos trabajadores vieron disminuir sus salarios y fuentes laborales. Finalmente, a comienzos de septiembre de 1945 Perón volvió a Berisso para asistir al funeral de Doralio Reyes (hermano del dirigente sindical Cipriano Reyes), asesinado en un enfrentamiento con militantes comunistas (James y Wolfson, 1987).

Si entre los meses de septiembre y octubre la situación laboral era crítica, la destitución de Perón y su posterior encarcelamiento en la Isla Martín García hicieron que los trabajadores de Berisso perdieran al único interlocutor estatal que había intervenido en sus reclamos. Así, el "17 de octubre, apenas comenzó el día, los piquetes de huelga se apostaron en las cercanías de los frigoríficos, frente a la fábrica textil, en las vías de acceso a la localidad." (Lobato, 2004: 242). Esas columnas obreras se dirigieron hacia la Plaza San Martín (La Plata) pidiendo la liberación de quien consideraban el único garante de sus derechos. Algunos de estos obreros terminaron el 17 de octubre de 1945 en la Plaza de Mayo (ciudad de Buenos Aires), dando por concluida una jornada que se volvería mítica y fundacional del peronismo.

6 Perón ocupaba los cargos de Secretario de Trabajo, Ministro de Guerra y Vicepresidente de la Nación en el gobierno del General E. Farrell (1944-1946). 
El enorme apoyo con el que Perón fue electo presidente de la República en 1946 empoderó a los trabajadores frigoríficos como un actor protagonista de esa parte de la historia nacional. Con el correr de los años la identificación obrera con el peronismo creció en la misma proporción con la que irían disminuyendo el resto de las identificaciones políticas y, centralmente, las identificaciones étnicas (ibídem). De esta manera, el peronismo logró integrar a un conjunto de personas - bajo la identificación de trabajadores- que se encontraban fragmentadas por origen nacional y diversas adscripciones políticas. Y aunque ese proceso no se diera sin tensiones y conflictos, el mismo quedo grabado a fuego en la memoria local (ibídem; James; 2004; lucci, 2012; Bretal, 2016).

Cabe recordar que en su momento fundacional el peronismo apeló a una identificación de "lo nacional» con "lo criollo», encarnado por el migrante interno, donde "lo extranjero" aparecía impidiendo el desarrollo nacional autónomo (Devoto, 2009). En suma, entre mediados de la década del 30 y mediados de la década del 50 Berisso fue caracterizada como una comunidad constitutivamente peronista, en detrimento de su identificación con un origen inmigratorio. La masiva irrupción del migrante interno en el espacio fabril y su posterior vinculación con el peronismo hicieron entrar en crisis el imaginario de una comunidad que se auto-representaba como esencialmente descendida de los barcos.

Años después, entre mediados de 1970 y principios de 1980, distintos actores de la sociedad civil y el Estado buscaron revertir el proceso señalado anteriormente. En 1978, en un contexto dictatorial caracterizado por la crisis terminal del tejido industrial de la ciudad ${ }^{7}$, algunas asociaciones étnicas locales y la intendencia municipal organizaron la primera edición de la Fiesta Provincial del Inmigrante ${ }^{8}$. Al articular las adscripciones étnicas, conmemorar un origen inmigratorio y representar la existencia de un vínculo armónico/acrisolado entre los miembros de la comunidad, la creación de Fiesta Provincial del Inmigrante buscó desarticular las adscripciones políticas, silenciar los recuerdos que unian a la ciudad con los orígenes del peronismo y despojar al presente de sus aristas conflictivas (Lobato, 2004). Como parte de este proceso, la Fiesta Provincial del Inmigrante instaló a los inmigrantes ultramarinos en el centro - y punto de origen- de la historia de Berisso, instituyéndolos en figuras míticas de la memoria local: héroes, pioneros y padres fundadores de una comunidad tan armónica como acrisolada (Herrera, 2018, 2019).

Cabe recordar que en la Argentina las asociaciones étnicas funcionaron como un espacio de la sociedad civil en el cual las elites dirigentes construyeron una identidad de clase media (Míguez, 1992) que, al reponer el mito de una nación homogéneamente blanca, acrisolada y de origen europeo, se opusiera al imaginario político peronista (Garguin, 2009). Así, durante la última dictadura cívico-militar (1976-1983), se abrió en Berisso una nueva estructura de oportunidades para el desarrollo de las identificaciones sociales, donde las identificaciones étnicas resurgieron mediante la recordación del pasado inmigratorio de la ciudad.

La inmigración europea y el peronismo forman parte de los procesos a partir de los cuales se estructuran las identificaciones colectivas en la ciudad de Berisso. Como así también las memorias oficiales sobre las que se sostienen dichos sistemas de identificación. De ello da cuenta

7 En 1969 cerró el frigorífico Armour y el Swift compró sus instalaciones, haciéndose cargo parcialmente del personal despedido. Al año siguiente el Swift declaró la quiebra y su gestión pasó a manos del Estado. Diez años después, este frigorífico cerró su planta.

8 Meses después de que Berisso fuera declarada, por decreto militar del gobernador de la Provincia de Buenos Aires, Capital Provincial del Inmigrante (Herrera, 2018). 
la enorme cantidad de marcas territoriales de la memoria (Jelin y Langland, 2003; Messina, 2011) que existen en su trama urbana. Al acercarnos a Berisso un cartel nos indica que hemos llegado a la "Capital Provincial del Inmigrante». Sus calles han sido nombradas con referencias a otras ciudades y países: Nueva York, Marsella, Londres, Constantinopla, Atenas, Cádiz, Hamburgo, Génova, Lisboa, Bilbao, Belfast, Italia, Polonia, República Árabe Unida, Grecia, República del Líbano, Yugoslavia, Albania, Rumania, Portugal, etc. Al caminar por esas calles encontramos una enorme cantidad de asociaciones étnicas y bustos de alguna figura reconocida internacionalmente: por ejemplo, los de N. Copérnico, de 1973, F.F. Chopin, de 2003, y T. Sevchenko, de 2011, colocados por la colectividad polaca y la colectividad ucraniana respectivamente. También podemos encontrar monumentos que refieren al extranjero, en torno a los cuales distintas asociaciones étnicas desarrollan sus prácticas conmemorativas: por ejemplo, el monumento Rupintojelis, de 2009, en torno al cual se reúnen los miembros de la comunidad lituana. Por otra parte, los bustos de Eva Duarte de Perón, Juan D. Perón y las placas conmemorativas que hay en el puerto no solo indican que desde ese «histórico lugar partieron las primeras columnas de trabajadores argentinos que liberaron al coronel Juan D. Perón en su glorioso 17 de octubre de 1945», sino que además definen a Berisso como la "Capital del Peronismo". A pocos metros de allí, un enorme mural y una placa conmemorativa (2005) rememoran escenas fundacionales del peronismo. Y si damos unos pasos más, encontramos un cartel con las figuras de Juan D. Perón y Eva Duarte de Perón y un monumento, de 2014, con placas conmemorativas que definen a Berisso como el «Km. 0 del Peronismo».

Imagen 1

Monumentos, placas, bustos y murales ligados a la inmigración en Berisso (Argentina)

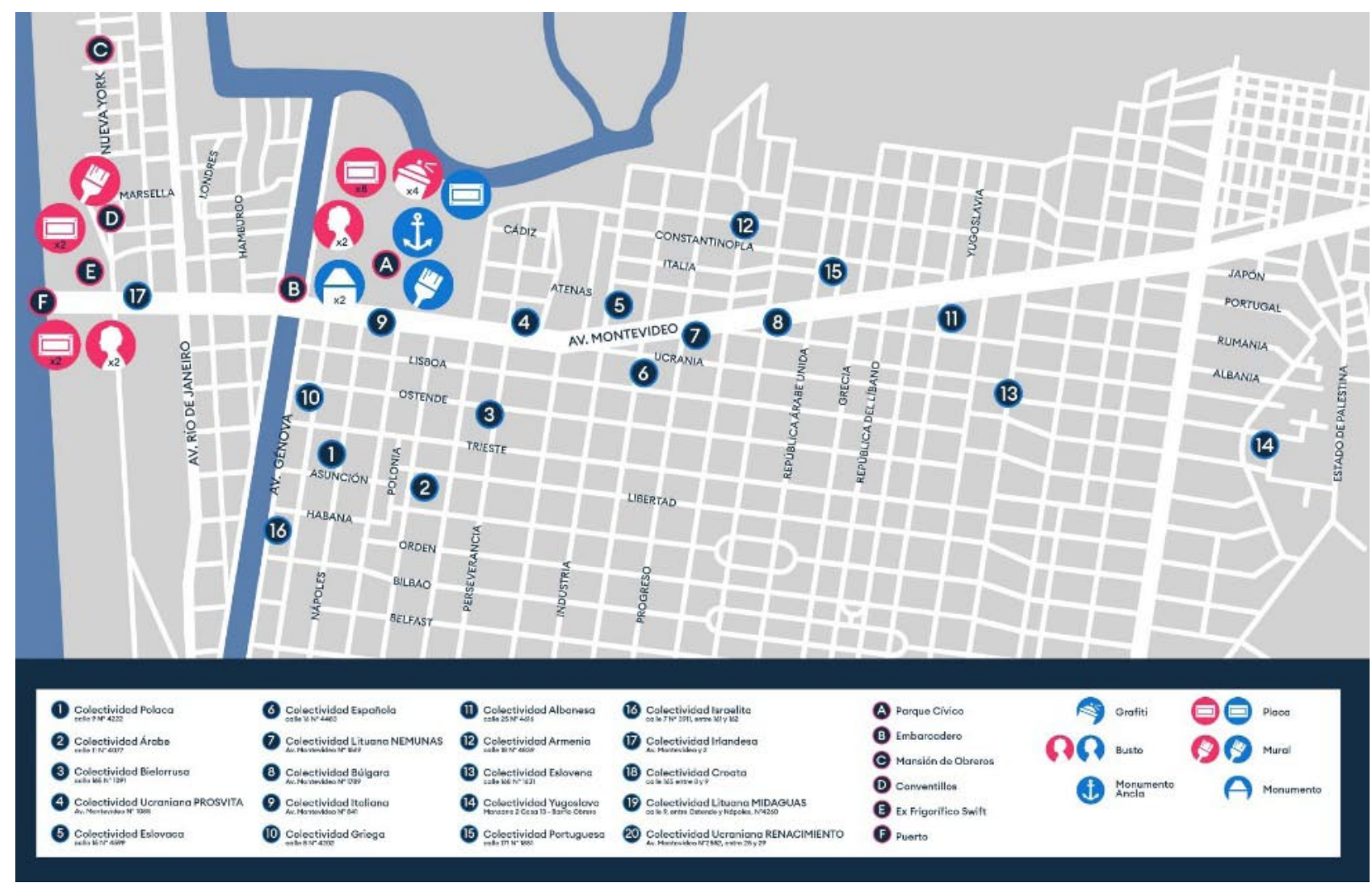

Fuente: elaboración propia. 
Sin embargo, en ese trayecto sobresalen tres lugares en los cuales las asociaciones étnicas locales y la intendencia municipal han logrado materializar uno de los ejes sobre los que se estructura la memoria oficial de la comunidad. Me refiero al modo en que institucionalmente fueron espacializados y son transmitidos los recuerdos ligados al pasado inmigratorio de Berisso en el Parque Cívico, la Curva de las Naciones y el Museo 1871.

\section{LUGARES DE MEMORIA, PRÁCTICAS CONMEMORATIVAS Y OBJETOS MNEMÓNICOS LIGADOS A LA INMIGRACIÓN ULTRAMARINA}

El hecho de que la mayoría de los ciudadanos de Berisso/la Argentina no haya transitado por la experiencia migratoria a la que remite el mito fundacional de la comunidad local/nacional, conlleva una dificultad creciente para recordar ese pasado de manera directa. Al escenificar el mito del crisol de razas, la Fiesta Provincial del Inmigrante repone y transmite uno de los ejes que estructuran la memoria oficial de la comunidad. Así, dicho ritual conmemorativo permite enfrentar las dificultades inherentes a la transmisión intergeneracional de la memoria oficial (Herrera, 2018, 2019).

Si bien la Fiesta Provincial del Inmigrante es la principal práctica conmemorativa a través de la cual se repone y transmite el origen inmigratorio de la comunidad, no es la única. Como veremos a continuación, distintos actores han espacializado una memoria colectiva ligada a la inmigración ultramarina en tres espacios de la ciudad: el Parque Cívico, la Curva de las Naciones y el Museo 1871. Como sabemos, el espacio es una dimensión clave en los procesos de memorialización: "sea marco social, anclaje material, receptáculo, soporte y/o vehículo, el espacio constituye un elemento activo en la significación y representación del pasado y la configuración de las memorias» (Messina, 2019: 60). Estos espacios serán entendidos aquí como lugares de memoria (Nora, 2008). Lugares donde la memoria viva, debido al cambio o la aceleración permanente que caracteriza a las sociedades contemporáneas, se vuelve historia. Estos lugares «nacen y viven del sentimiento de que no hay memoria espontánea. [...] Si lo que defienden no estuviera amenazado, ya no habría necesidad de construirlos. Si los recuerdos que encierran se vivieran verdaderamente, serían inútiles» (ibídem: 25).

En su sentido material, simbólico y funcional, estos lugares dan cuenta de la materialización, espacialización y transmisión de las memorias oficiales de las naciones modernas. Y esto no solo se evidencia en las prácticas conmemorativas que distintos actores de la sociedad civil y el Estado desarrollan en ellos, sino además en las marcas territoriales y en los objetos investidos de sentidos memoriales que alli se exhiben.

\subsection{El Parque Cívico}

El espacio donde se encuentra ubicado el Parque Cívico alojó, a fines del siglo XIX, los saladeros San Juan y San Luis. Décadas más tarde, el frigorífico Swift compró las instalaciones de ambos saladeros. En 1947 (durante el primer gobierno de Juan D. Perón) el Gobernador de la Provincia de Buenos Aires decretó que este espacio - y todo lo que había en él- debía ser 
expropiado para formar un parque denominado "La Lealtad». El proyecto ${ }^{9}$ no se llevaría a cabo y, al año siguiente, este espacio recibió la designación oficial de Parque Cívico.

Como señaló James (2004), Berisso no posee una plaza central. Ese lugar que en la mayor parte de las ciudades argentinas suele enfrentar a un edificio estatal con un edificio religioso, en Berisso no existe. Sin embargo, el Parque Cívico cumple la misma función mnemónica que esas plazas: al brindar testimonio de la historia local/nacional, funciona como un sitio dedicado a la rememoración y la conmemoración. Sobre él encontramos la mayor cantidad de marcas territoriales de la memoria que hay en la ciudad.

Entre las que recuerdan su pasado fabril se encuentra una placa de 2008, colocada sobre los restos del saladero de Luis Berisso y un Monumento a los Trabajadores de la Carne ${ }^{10}$. Por su parte, entre las marcas que recuerdan el vínculo de la ciudad con los orígenes del peronismo se encuentran los bustos de Eva Duarte y Juan D. Perón (debajo de los cuales hay varias placas, una de las cuales define a Berisso como la "Cuna del Peronismo») ${ }^{11}$, un mural que incluye sus rostros y frases de la iconografía peronista. Por su parte, el «Monumento al Gaucho» (de 1998) erige a este actor en figura central de la identidad nacional y recuerda, a través de él, a los migrantes internos que llegaron a Berisso a fines de la década de 1930.

Sin embargo, en tanto referencia mnemónica, la inmigración ultramarina reúne la mayor cantidad de marcas territoriales que hay en el Parque Cívico: allí se encuentra el "Monumento a los Inmigrantes» (1977), un monumento/mural titulado "La Inmigración y su aporte cultural» (de 1997) (grafica el desembarco de inmigrantes a la costa locales), un ancla que recuerda el origen ultramarino de la población local y un enorme mural que narra la historia de la ciudad vinculando su origen con la llegada, en barco, de distintos inmigrantes. Ninguna de estas marcas muestra signos de abandono ya que el estado municipal las pinta regularmente. Claro está, lo importante no solo es la cantidad de marcas que existen en un mismo lugar, sino el vínculo que distintos actores entablan con ellas. Algunas de las asociaciones étnicas locales se reúnen alrededor de estas marcas para realizar diversas prácticas conmemorativas. Por ejemplo, el "Monumento a los Inmigrantes» es el lugar elegido por la Colectividad Armenia para recordar el Genocidio Armenio y por las asociaciones ucranianas (Asociación Ucraniana Renacimiento y Asociación Ucraniana de Cultura Prosvita) para conmemoran la independencia de ese país.

Estas marcas territoriales de la memoria han sido colocadas de recordar y evocar el pasado inmigratorio de la comunidad, dando forma a una memoria colectiva a partir de la cual la comunidad se recrearía a sí misma (Lefebvre, 1971). A través de ellas, distintos actores institucionales han materializado un pasado mítico de la comunidad, transmitiendo una memoria que, se supone, debería ser compartida por los ciudadanos de Berisso. Pero a la vez, a través de estos monumentos, bustos y murales se enuncia a los héroes y mitos fundacionales de la comunidad, instituyendo a los inmigrantes ultramarinos en modelos a partir de los cuales la sociedad berissense se vería reflejada (Ansaldi, 1996).

9 Decreto $^{\circ} .^{\circ} 25.916$ (1947).

10 Inaugurado en 2015, para los festejos del $144^{\circ}$ aniversario de Berisso.

11 Las placas que hay bajo de estos bustos fueron colocadas durante el período 1990-2004. Sin embargo, los bustos de Juan D. Perón y Eva Duarte de Perón fueron colocados luego del restablecimiento democrático, en 1983 (James, 2004). 


\section{Imagen 2}

Monumento a los Inmigrantes, Berisso (Argentina), 2013

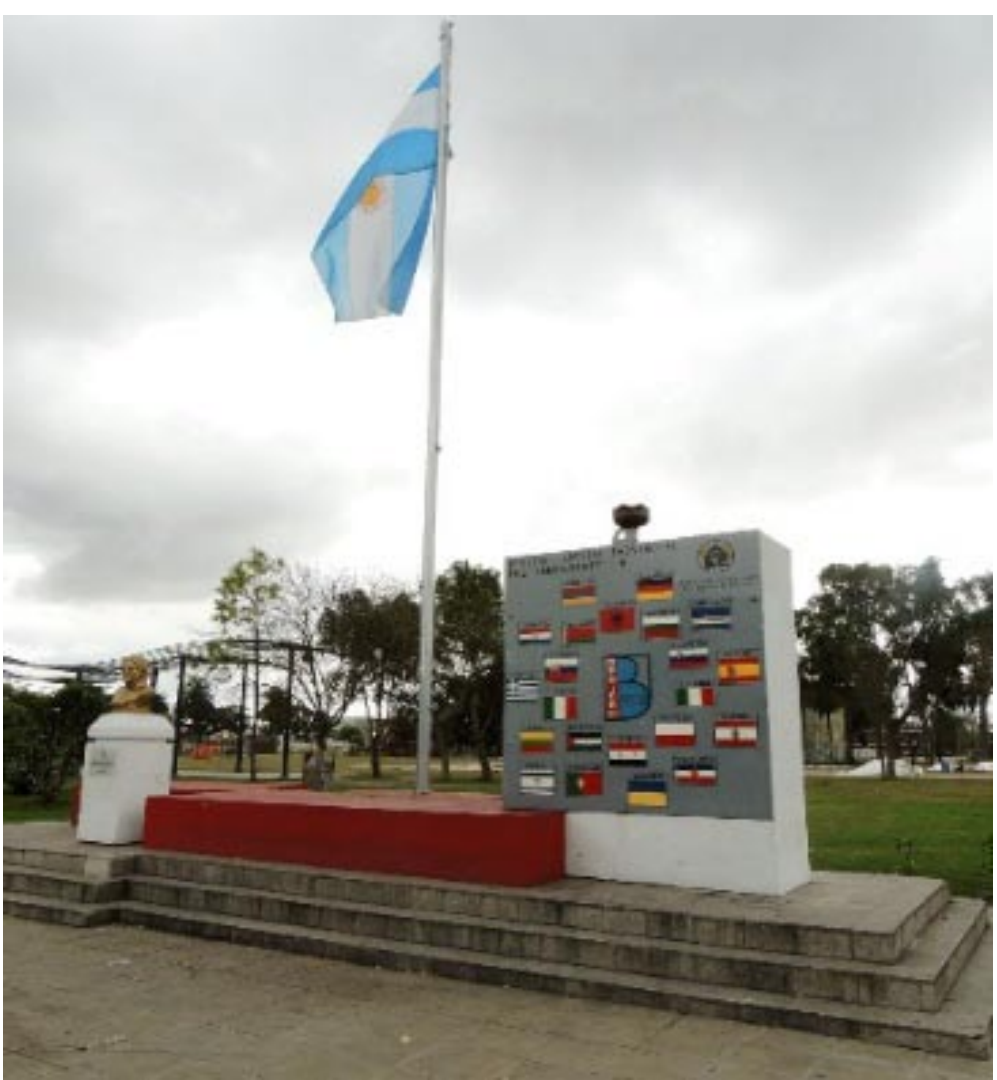

Fotografía del autor.

\section{Imagen 3}

Monumento «La Inmigración y su aporte cultural», Berisso (Argentina), 2013

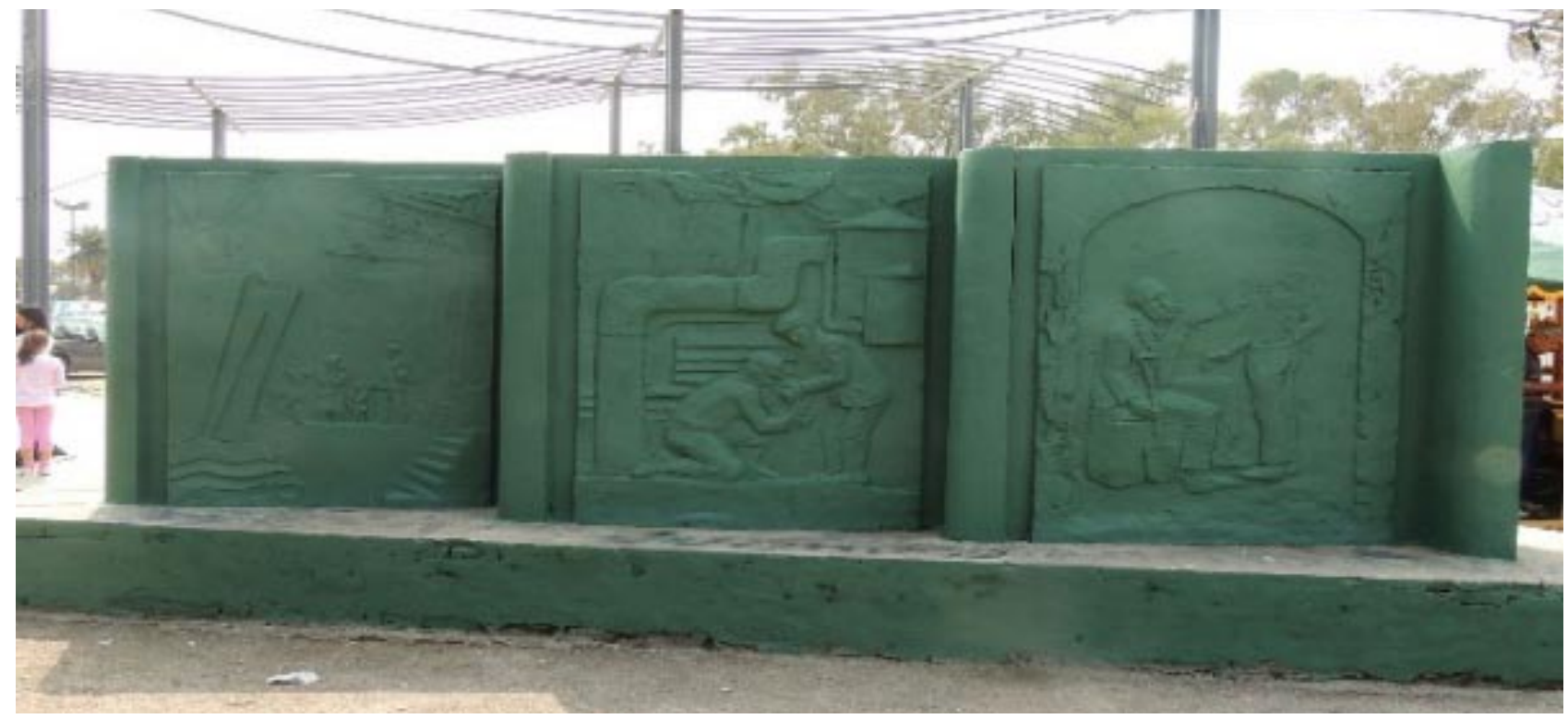

Fotografía del autor. 


\section{Imagen 4}

Parte izquierda del mural que narra la historia de Berisso (Argentina), situando a un barco como punto de origen y frente al cual hay colocada un ancla, 2018

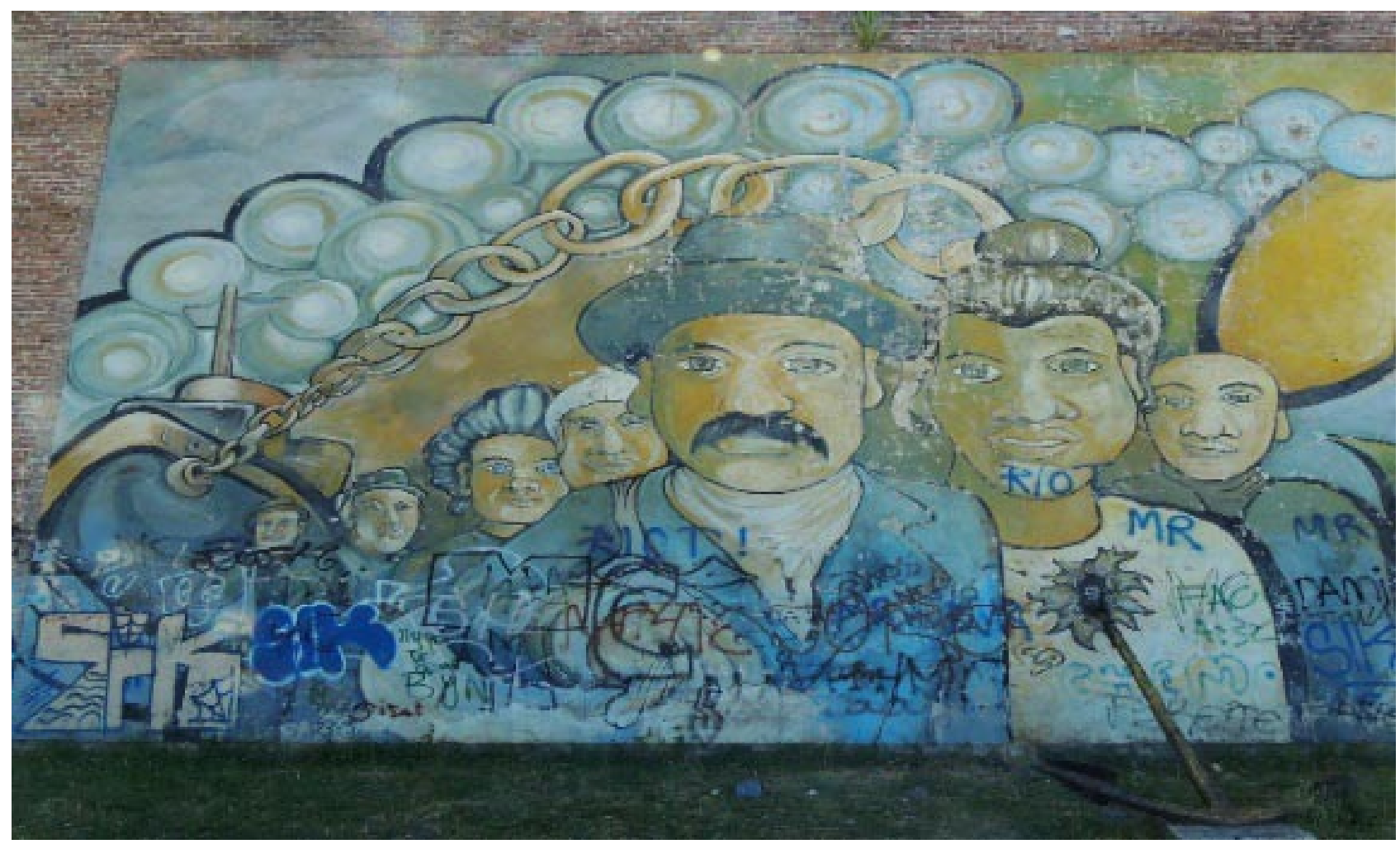

Fotografía del autor.

\subsection{La Curva de las Naciones}

A fines del siglo $x x$ algunas fechas, hechos $y$ actores del pasado de Berisso formaron parte de un cambio en las prácticas conmemorativas desarrolladas por las asociaciones étnicas locales y la intendencia municipal. Para entender este proceso es necesario recordar que Berisso logró su autonomía el 3 de abril de 1957 (al separarse administrativamente de La Plata) y que su nombre fue elegido para homenajear al empresario italiano Juan Berisso (quien inauguró la historia fabril de la ciudad el 24 de junio de 1871 - fecha que le dará nombre al museo-, poniendo en funcionamiento el saladero San Juan).

Hasta 1998 la intendencia disponía que el aniversario de Berisso se festejara el 3 de abril, conmemorando su autonomía. Sin embargo, el 11 de diciembre de ese año se promulgó la ordenanza n. ${ }^{\circ} 2247^{12}$, declarando "padre fundador de la ciudad" a Juan Berisso y trasladando el festejo de su aniversario al 24 de junio para, así, conmemorar la fecha en que comenzó a operar su saladero ${ }^{13}$.

12 Proyecto presentado en 1998 por el Dr. O. Alcoba (miembro del Consejo Deliberante de Berisso, Partido Justicialista).

13 En el año 2000 la Cámara de Diputados de la Prov. de Buenos Aires reconoció al 24 de junio como fecha de fundación de Berisso (Ley 12.440). El proyecto fue presentado por O. J. Mercuri (Partido Justicialista). 
Si durante el centenario de la Argentina la decisión sobre qué fecha debía ser conmemorada implicó una definición sobre el pasado y el presente de la nacionalidad (Cattaruzza, 2007), el traslado del origen de Berisso hacia un pasado más remoto no solo implicó un cambio en los sentidos de la conmemoración sino, además, un cambio en los actores que ella empodera: se pasó de conmemorar un origen administrativo a conmemorar un origen industrial, donde el centro de la escena dejó de estar ocupado por las instituciones que lograron la autonomía de la ciudad ${ }^{14}$ y pasó a estar ocupado por un inmigrantes europeo.

En el año 2012, al festejarse el $141 .^{\circ}$ aniversario del (nuevo) origen de Berisso, el concejal que impulsó aquella ordenanza, afirmó:

«Recién hace unos años se acordó una fecha para conmemorar la fundación de la ciudad. [...] Se eligió el día en que comienza a operar el saladero San Juan. Obviamente es una designación simbólica, pero que ya fue aceptada por la gente de la ciudad y forma parte de su calendario de celebraciones, representándola e identificándola tanto como un documento de identidad. Esta fecha es parte de su fisonomía tanto como la Fiesta del Inmigrante..1 ${ }^{15}$

El vínculo entre la fecha en que se conmemora el aniversario de la ciudad y su historia inmigratoria no solo se evidencia a partir del origen nacional de su "padre fundador» o en menciones a la Fiesta Provincial del Inmigrante como la expuesta anteriormente, sino además en la elección del lugar donde se realiza la conmemoración y en las prácticas que allí se desarrollan. La conmemoración del $143 .^{\circ}$ aniversario de la ciudad (2014) se realizó en "La Curva de las Naciones» ${ }^{16}$ reinaugurando un monumento denominado "Banderoteca de las Colectividades» ${ }^{17}$, situado a pocos metros del "Monumento a la Música Inmigrante» ${ }^{18}$. Allí, el subsecretario de Planificación y Gestión de Obra Pública, acompañado por los representantes de las asociaciones étnicas locales y el intendente municipal, inició el acto describiendo la nueva Banderoteca:

«La obra presenta dos líneas de mástiles separados por una fuente que simboliza el océano. Es una obra que simboliza el espíritu inmigrante de la ciudad, que tiene que ver con la historia de cada uno de los berissenses.»

Posteriormente se izaron las banderas de los países representados por las distintas asociaciones étnicas, las banderas de la Argentina, de la Provincia de Buenos Aires y de Berisso. Como todo emblema, la bandera y el escudo portan una enorme carga iconográfica, que, en el caso de Berisso, está vinculada a la inmigración ultramarina. En el centro de la bandera podemos ver un barco, símbolo «de la afluencia de los inmigrantes». Por su parte el escudo posee cinco líneas onduladas que "hacen referencia a una ciudad ribereña», siendo su forma rectangular

14 En 1956 se conformó la Comisión Popular Pro-Autonomía Municipal, integrada por la Asociación Amigos de Berisso, Ital Club, Asociación Ucrania Prosvita, Centro de Fomento Barrio Obrero, Centro de Fomento Camoatí, Hogar Bielorruso, Centro de Fomento Villa Banco Constructor, Honor y Patria, Centro de Fomento Tambor de Tacuarí, Bomberos Voluntarios, Centro de Estudiantes y Egresados, Fortín Gaucho, Rotary Club, Centro Comercial, Club Social y Deportivo Vértigo, Biblioteca Aristóbulo del Valle y Asociación Amigos de Berisso.

15 Dr. O. Alcoba en «El Mundo de Berisso», edición del 22 al 28 de junio del 2012.

16 Camino de ingreso a la ciudad.

17 La vieja Banderoteca fue inaugurada el 24 de junio en 1971 (a propuesta de la Municipalidad) en el marco de los festejos realizados durante el centenario de Berisso.

18 Inaugurado en 1973, a propuesta de la Municipalidad. 
y su partición «atípicas a todos los escudos de distintas nacionalidades debido a que Berisso es un verdadero crisol de razas» ${ }^{19}$.

Después de que se izaran las banderas, los presentes entonaron las estrofas del Himno Nacional Argentino y el Himno de Berisso, de 1990, emblema que vincula el origen de la comunidad local con la llegada de inmigrantes europeos y erige a Juan Berisso en su figura central. Allí los presentes cantaron estas estrofas:

Hija del río, adolescente y bella, te enviaron amores, el hambre y la guerra. Te dio su apellido Juan, aquel pionero, que trajo la industria de los saladeros.

En todos los idiomas te pidieron pan. En todos los idiomas te pidieron paz. Distintos colores de piel y banderas, iguales deseos de una vida nueva.

Berisso, barro, monte y esperanza... fábrica y obreros, puerto, barco y añoranza.

Cautivaste a todos, tú, dulce muchacha, sembraron tu vientre con pequeñas patrias.

Maduró en tu seno ese fruto nuevo y diste a luz niños de todos los pueblos.

Tu amor es ejemplo para los humanos, no importa el origen json todos hermanos!

Debido a que han sido elaborados a partir de los mismos ejes que estructuran la memoria colectiva, los emblemas juegan un rol central en la reproducción de los imaginarios sociales (Baczko, 2005). Al recordar un pasado ligado a la inmigración ultramarina, la bandera, el escudo y el himno de Berisso permiten reconstruir un imaginario de la comunidad berissense tan armónico como acrisolado. Pero, claro está, estos emblemas no logran dicho efecto por sí mismos, sino que deben ser puestos en escena durante prácticas conmemorativas como la anteriormente narrada.

Ahora bien, el himno de Berisso es el emblema que muestra con mayor claridad el vínculo entre memoria oficial, imaginarios sociales e identidades colectivas. Su entonación crea una unisonancia en la cual la imagen de pertenencia a la comunidad se vuelve extremadamente potente: allí, cada persona pierde su voz individual en un relato colectivo que lo identifica e incluye. Como señaló Anderson, «en tales momentos, personas del todo desconocidas entre sí pronuncian los mismos versos con la misma melodía. La imagen: unisonancia [...]. La realización física de la comunidad imaginada en forma de eco» (2007: 204).

Es importante resaltar que el imaginario armónico sobre la comunidad se funda en la existencia de un parentesco ficticio, construido a partir de la identificación de Berisso con una mujer y la presencia de una metáfora biológica según la cual todos los miembros de la comunidad tienen un mismo origen, el vientre de una mujer (Mostov, 2000), lo cual convierte en hermanos de sangre a todos los ciudadanos de Berisso. Al otorgarle significación cultural a hechos biológicos, el himno de Berisso amplía la definición de familia e incluye en ella a individuos que no poseen ninguna relación de sangre ni de matrimonio. Debido a su capacidad para vincular a personas que no comparte esos lazos, el parentesco ficticio ha sido caracterizado como una forma de mantener integrados y unidos a los miembros de un sistema social, y por lo tanto al mismo sistema (Barfield, 2000). Así, mediante la entonación del himno los asistentes a este ritual conmemorativo fueron interpelados como hermanos de una misma familia.

19 El Escudo fue creado en 1967 y la Bandera en 2003. Fuente: http://www.berisso.gov.ar/historia.php 
Luego de entonar aquellas estrofas, el intendente municipal cerró el acto manifestando:

«En cada una de estas banderas que hoy enarbolamos hay un sueño. El sueño de nuestros abuelos que vinieron en búsqueda de un lugar que no conocían y en el que establecieron sus familias y criaron a sus hijos; en el que buscaron lugares para reunirse y mantener viva su cultura. Hoy recordamos el desarraigo y esos sacrificios para entender a nuestra ciudad, que es distinta a otras, con nuestro puerto que nos marca definitivamente como una sociedad de integración y tolerancia.»

El pasaje anteriormente narrado, desde la conmemoración de un origen administrativo y emancipatorio a la conmemoración de un origen inmigratorio y fabril, ilumina un cambio fundamental en las dinámicas conmemorativas de la ciudad, a partir del que los inmigrantes ultramarinos adquieren mayor importancia dentro de la memoria oficial. De esta manera, los inmigrantes europeos son instituidos en figuras míticas de la memoria local: héroes, pioneros y padres fundadores.

Si todo calendario oficial se convierte en un espacio en disputa (debido a su capacidad para traer al presente distintas lecturas del pasado), el cambio de fechas aquí narrado nos recuerda que las preguntas por el origen (dónde está, cuál es, qué sentidos porta, cómo conmemorarlo) se responden únicamente desde el presente. Esas respuestas estarán, inevitablemente, atravesadas por acuerdos, tensiones y disputas sobre los modos en que una sociedad se imagina a sí misma.

\section{Imagen 5}

Banderoteca, Berisso (Argentina), 2015

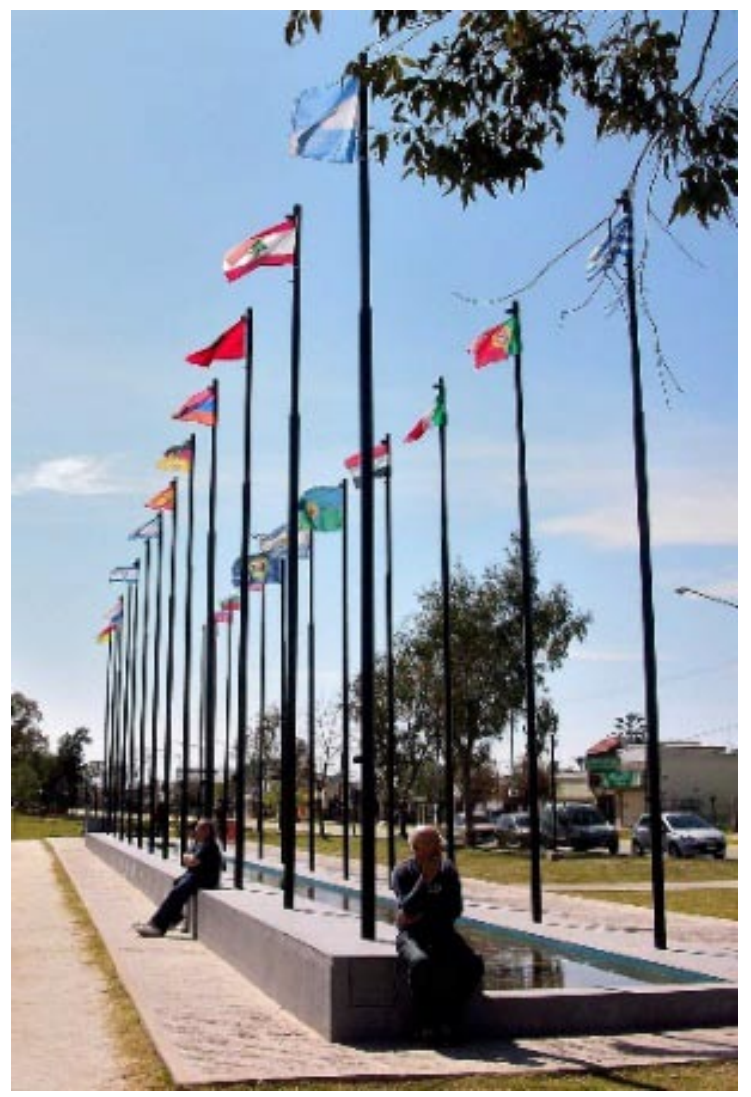

Fotografía del autor. 


\subsection{El Museo 1871}

Fundado el $1^{\circ}$ de julio del 2001, el Museo 1871 expone la historia de Berisso a partir de una serie de elementos que vinculan a la población local con el mundo del trabajo, el peronismo y la inmigración ultramarina. Si bien es un ente autónomo, el museo ha recibido reconocimiento y el apoyo del municipio: sin ir más lejos, el edificio donde se encuentra ubicado fue cedido por el municipio en el año 2005.

Su público está conformado, mayoritariamente, por alumnos de los niveles inicial, primario y secundario. El personal del museo ha elaborado una serie de juegos a través de los cuales pretende que los visitantes puedan (re)conocer la historia de la ciudad y vincularla con sus propias vidas. Algunos de esos juegos «nos transportan a la época dorada de Berisso», época «que la llevó a recibir el nombre de "La capital del inmigrante». Otros juegos demandan la lectura del cuento "Luz Gutiérrez viaja al pasado». A partir de él los visitantes deben responder preguntas como «¿En dónde nacieron las bisabuelas de Ana y Luz? ¿Y el abuelo José? [personajes del cuento] ¿Cómo llegaron a Berisso? y los abuelos de ustedes ¿dónde nacieron?». Junto a estos cuentos se exhiben algunos "relatos migrantes», a través de los cuales el museo busca que los visitantes recuerden «las historias de quienes habitaron esta localidad a principios de siglo xx." Así, a partir de la lectura de dos historias (sobre un matrimonio entre inmigrantes griegos y el destino de una joven polaca) los visitantes deben responder algunas preguntas: «¿De dónde venimos nosotros? ¿Tenemos historias de este tipo en nuestras familias? ${ }^{20}$. Estos materiales dan cuenta de la orientación pedagógica que posee el museo, donde la inmigración ultramarina ocupa un lugar importante entre los recuerdos que la institución busca reconstruir y transmitir.

El museo fue creado por Luis Guruciaga, un vecino de la ciudad que a lo largo de su vida coleccionó los objetos, documentos y fotografías que actualmente se exhiben en él. El rol jugado por Guruciaga en la conformación del museo da cuenta del pasaje de la memoria a la historia y permite explicar la expansión -más allá de los límites del campo académico del deber de memoria del deber de memoria que desarrollan distintos grupos sociales para resguardar su identidad (Nora, 2008). Como parte de una extensa serie de actividades dedicadas a la preservación y difusión de la historia local, este "emprendedor de memoria» (Jelin, 2002) publicó una serie de libros. Uno de ellos, Berisso. Fotomemoria, en dos volúmenes, reúne algunas de las fotografías que actualmente se exhiben en el museo. El índice de estos volúmenes señala que las fotografías publicadas fueron agrupadas por temáticas generales: "Las viviendas», "Las entidades», "La música», etc. Sin embargo, el primer capítulo de ambos volúmenes está dedicado a "Los inmigrantes», dejando en evidencia que la inmigración es el eje a partir del cual Guruciaga cuenta la historia de Berisso, su punto cero, su origen. En este marco Guruciaga instituye al inmigrante ultramarino en figura mítica de la memoria local: padre fundador, pionero, poseedor de un conjunto de valores morales socialmente legitimados como el esfuerzo, el trabajo y la solidaridad. Así, dirá: "La ciudad de Berisso nace en 1871 cuando Juan Berisso instala [...] el saladero de carnes. [...] Podríamos considerar a este genovés como un símbolo y un prototipo del inmigrante emprendedor y pionero» (Guruciaga, 1995: 13, cursivas nuestras).

La exposición del museo se encuentra dividida en siete salas: del Trabajo, de Ocio y Vida Cotidiana, de Educación, de la calle Nueva York, de Fotografía, de la Mujer y de Migraciones. Pese

20 Fuente: http://museo1871berisso.org.ar/ 
a no ser un museo dedicado únicamente a la inmigración, todas las salas poseen referencias a ella: sin ir más lejos, el banner que inaugura el recorrido museográfico está elaborado sobre la fotografía de un picnic realizado por inmigrantes españoles en 1918.

La Sala de Migraciones es uno de los espacios museográficos que, según Alegría (2012) podemos encontrar en los «Museos Patria». Estos espacios son, a la vez, un templo sacro y una vitrina cívica donde se exhibe el panteón de héroes nacionales. En nuestro caso, la sala narra uno de los hitos fundantes de la memoria local/nacional y celebra a sus héroes: la llegada de inmigrantes ultramarinos a las costas berissenses/argentinas durante el período de entre siglos $(X \mid X-X X)$. Como ha señalado Pontes (2016), al integrar la historia de la inmigración con la construcción de la Nación, este tipo de museos adoptan la lógica del nacionalismo museográfico. Y dentro de los museos analizados por Pontes (ibídem), la Sala de Migraciones se asemeja a los museos de la inmigración existentes en los Estados Unidos y Canadá. A diferencia de sus pares europeos (donde la población inmigrante procede de antiguos territorios coloniales), la población de origen inmigrante es instituida en el grupo poblacional dominante, relegando a las poblaciones autóctonas a un papel marginal y subalterno. Así, frente a la inmigración ultramarina, los migrantes internos que comenzaron a llegar a Berisso a fines de la década de 1930 y los inmigrantes latinoamericanos que llegaron durante las últimas décadas del siglo xx y las primeras del siglo xxI ocupan un lugar subalterno dentro de la exposición.

Como sabemos, la noción de lugar de memoria (la territorialización o espacialización de las prácticas de conmemoración) ha ocupado un lugar central en el campo de los estudios de la memoria social. Esa centralidad hizo que los objetos investidos de sentidos memoriales queden en un lugar secundario. Sin embargo, estos objetos tienen un lugar importante en los trabajos de memoria ya que poseen la capacidad de contenerla, desbloquearla, reconstruirla y/o transmitirla. Y pese a que el pasado se ha incrustado en los objetos transportados por los migrantes, su análisis ha ocupado un lugar marginal dentro del campo de los estudios migratorios de la Argentina (Da Orden, 2004, 2010; Ceva, 2005; Bjerg, 2019).

En la Sala de Migraciones encontramos una serie de objetos que pertenecieron a los propios inmigrantes (vajilla, sombreros, anteojos, abanicos, guantes), documentos personales (cédulas de identidad, pasaportes, certificados de antecedentes penales, certificados de matrimonio, certificados de nacimiento, carnet de adhesión a partidos políticos, certificados de participación en el Ejército Argentino, libretas de ahorro postal), testimonios escritos (cartas) y una enorme cantidad de fotografías y valijas. Por un lado, estos objetos señalan el carácter ultramarino de la inmigración que llegó a Berisso. El barco es la figura que los aglutina: fotos de inmigrantes junto a los barcos, el menú de la cena que se ofrecía en los barcos, pasajes en barco, documentos del viaje en barco y estuches de tela elaborados por las compañías navieras donde los inmigrantes guardaban sus documentos, son parte de los objetos exhibidos. Por otra parte, como ha señalado Lafont-Couturier (2007), los objetos investidos de sentidos memoriales suelen ser presentados por los museos de la inmigración junto con el equipaje (baúles, maletas, sacos) que transportaban los inmigrantes, haciendo que la maleta se vuelva un elemento simbólico y un dispositivo museográfico. La «narrativa de la maleta» (LafontCouturier, 2007) permite contar la experiencia del viaje, poner en escena los elementos que los migrantes trajeron consigo y mostrar cómo contribuyeron a la construcción de la Nación: en el Museo 1871 las maletas no solo son un objeto recurrente en la exhibición, conteniendo objetos personales que los inmigrantes trajeron a la Argentina, sino que una de ellas es el objeto que ocupa el centro de la Sala de Migraciones. 
Por último, quisiéramos señalar que la exposición de estos objetos muestra la existencia de un trabajo de encuadramiento de la memoria (Rousso, 1987; Pollak, 2006) realizado por los distintos emprendedores de la memoria que trabajaron en el museo, fundamentalmente el propio Guruciaga, un trabajo de memoria a través del cual se busca resaltar, por un lado, la existencia de un exitoso proceso de incorporación de los inmigrantes a la sociedad argentina $y$, por otro, su respeto y compromiso con ella. Respecto a la incorporación de los inmigrantes a la sociedad argentina (su integración), muchas de las fotos muestran a los inmigrantes realizando una práctica icónica del folklore nacional y la tradición gauchesca, beber mate. Por su parte, los certificados de participación en el Ejército Argentino, la colocación de imágenes de próceres argentinos en el interior de las asociaciones étnicas, las imágenes de los hijos de inmigrantes en escuelas públicas y la participación de sus asociaciones en actos patrios, buscan mostrar el respeto y el compromiso de los inmigrantes con la nación que los acogía. En suma, evidenciamos la existencia de un trabajo de memoria a través del cual no solo se instituye a los inmigrantes en figuras míticas de la memoria local y se presenta su llegada como punto cero de la historia de Berisso, sino que además logra legitimar a dichos actores mostrando su exitosa integración, respeto y compromiso con la sociedad argentina.

Imagen 6

Gigantografía de inmigrantes y sus maletas, Museo 1871, Berisso (Argentina), 2020

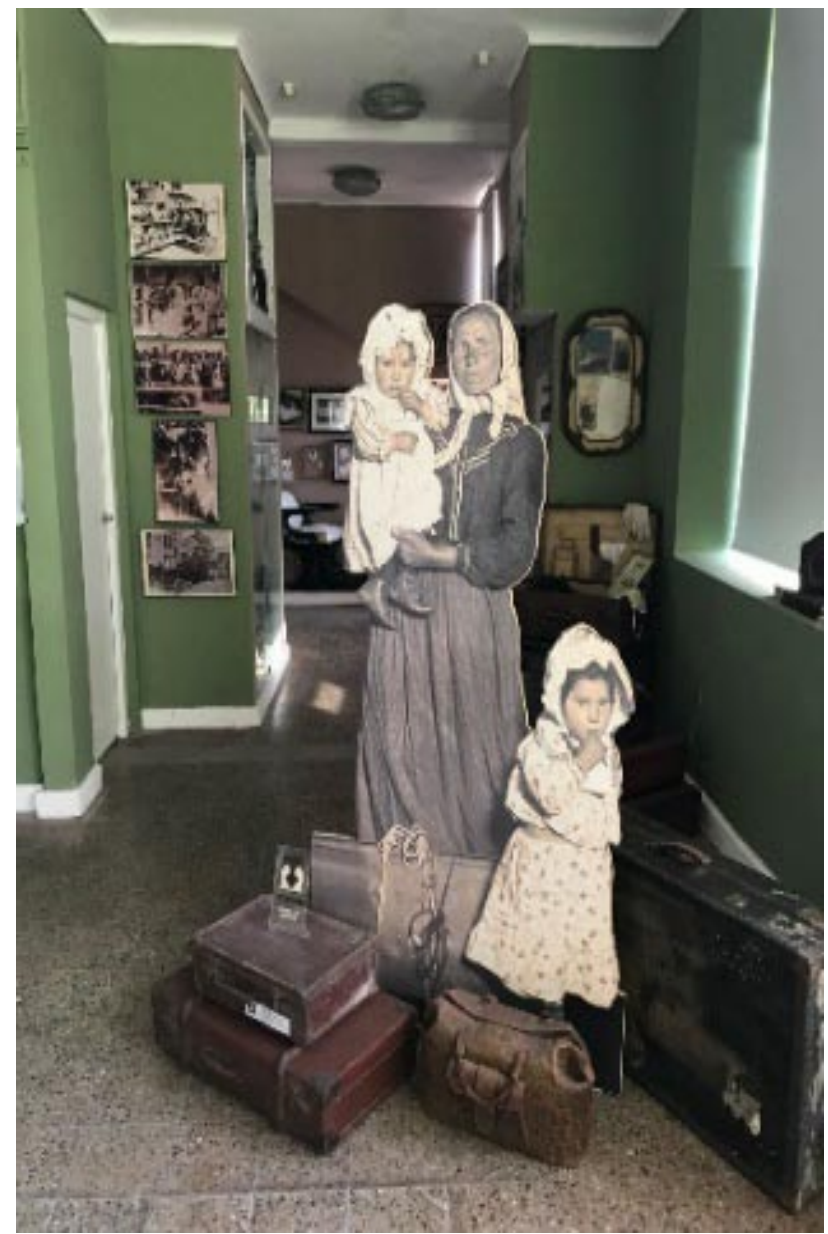

Fotografía del autor.

\section{Imagen 7}

Maleta que ocupa el centro de la Sala de Migraciones, Museo 1871 Berisso (Argentina), 2020



Fotografía del autor. 


\section{Imagen 8}

Inmigrantes lituanos en las costas berissenses, 1935. Museo 1871, Berisso (Argentina), 2020.

El hombre de la derecha le ceba mate a la mujer que se encuentra a su lado

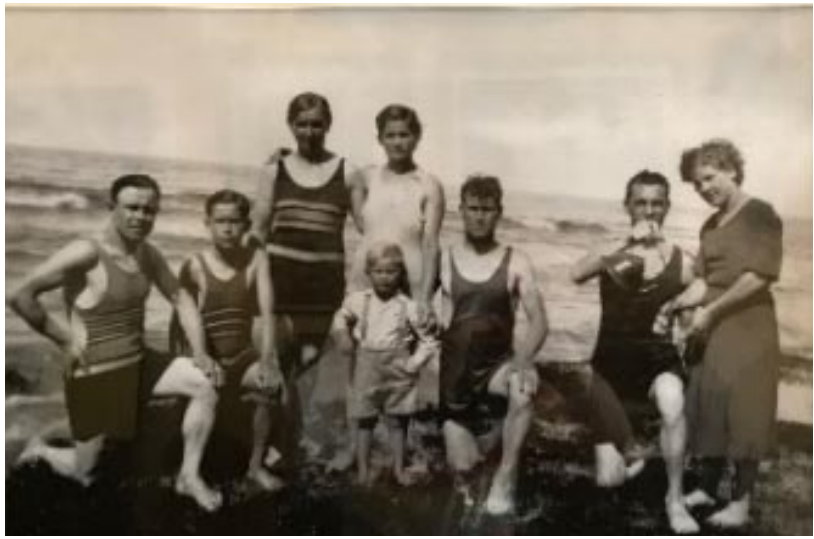

Fotografía del autor.

\section{Imagen 9}

Representantes de la colectividad polaca durante un desfile patrio argentino, 1937 , portando las banderas nacionales de Polonia y la Argentina, 2020

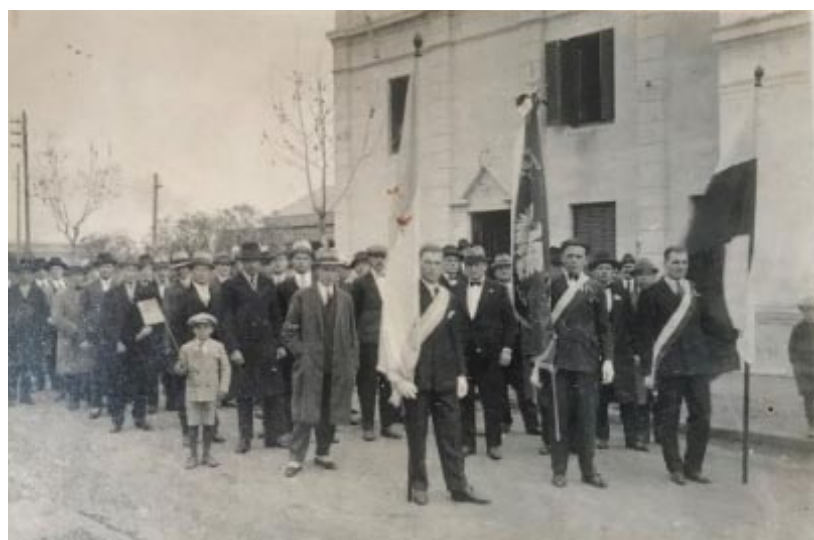

Fotografía del autor.

\section{Imagen 10}

Miembros de la Comisión Directiva de la Colectividad Bielorusa Vostok, 1941. Institución decorada con imágenes de próceres nacionales argentinos, 2020

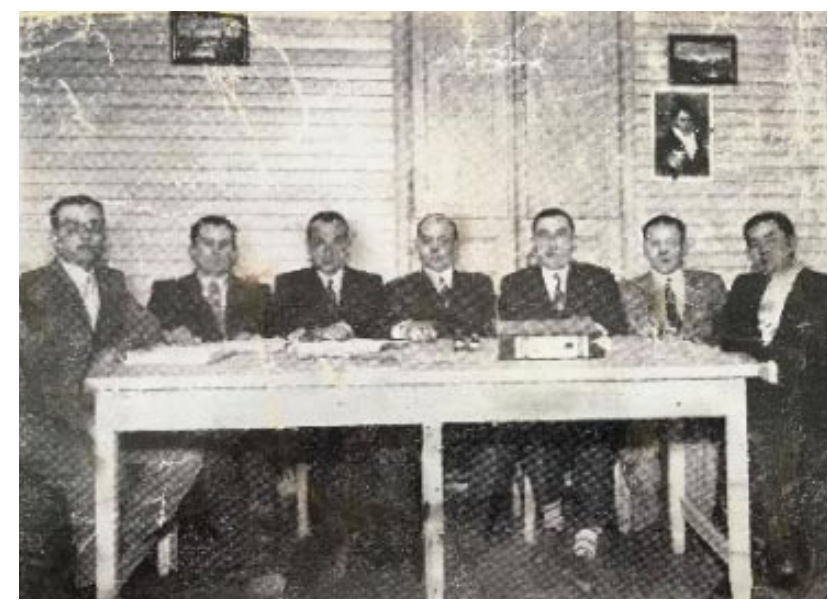

Fotografía del autor.

\section{REFLEXIONES FINALES}

Gérard Noiriel (1996) señaló que, en Francia, la construcción estatal de una memoria nacional relegó a la inmigración a un «no lugar de memoria». Si bien sabemos que en la Argentina sucedió exactamente lo contrario - es decir, que la inmigración es parte de los mitos fundacionales que sostienen la memoria oficial de la Nación (Bjerg, 2016)- el material etnográfico 
elaborado para este artículo nos permitió mostrar el modo en que dicho proceso se expresa y reproduce a nivel local. Al reducir la escala pudimos analizar el rol que poseen algunas instituciones de la sociedad civil (las asociaciones étnicas locales) y del Estado (la intendencia municipal) en la reproducción de uno de los ejes que estructuran la memoria oficial de la comunidad. Una memoria cultural que - por oposición a la memoria comunicativa, transmitida oralmente en el seno familiar - es transmitida intergeneracionalmente a partir de marcos institucionales (Assmann, 2010).

El recuerdo del rol jugado por los obreros berissenses en los orígenes del peronismo y el recuerdo del rol jugado por la inmigración ultramarina en los orígenes de la comunidad berissense/argentina, constituyen los ejes sobre los que se estructura la memoria oficial de la ciudad/nación. Sin embargo, mientras los recuerdos locales sobre el peronismo no siempre han sido armónicos ni unificadores y existe en torno a la inmigración ultramarina una memoria edulcorada, a-conflictiva y unificadora. Respecto al peronismo, lo dicho anteriormente se evidencia al contraponer la simbología del Parque Cívico con la de la plaza 17 de Octubre: mientras en el Parque Cívico vemos un grafiti con la frase «Tu espíritu de unidad nacional no se destruye", la Plaza 17 de Octubre - habiendo sido construida para recordar la jornada fundante del peronismo- presenta en su monumento una iconografía socialista que se aleja de los emblemas unificadores del peronismo (James, 2004): allí se lo puede ver a Perón, con sus manos en alto delante de un sol naciente y dos brazos que rompen los eslabones de una gruesa cadena. Nada de esto sucede con la inmigración: en Berisso no hay una sola marca territorial, monumento o práctica conmemorativa vinculada con la inmigración ultramarina que implique un corrimiento respecto al aura unificadora y armónica que se posa sobre ella. Desde su soledad, el Monumento al Gaucho (recordando a la migración interna que llegó a Berisso durante la década de 1930 y erigiendo al gaucho en figura del ser nacional) se muestra como la única figura que le disputa un lugar en el imaginario local/nacional.

En suma, hemos puesto en evidencia la existencia de una representación idealizada del pasado inmigratorio de la comunidad. Un pasado donde el proceso de integración de los inmigrantes ultramarinos a la sociedad de acogida es absolutamente exitoso. La inmigración ultramarina no solo ocupa el punto cero de la historia de la ciudad, sino que, además, el inmigrante ultramarino es instituido en figura mítica de la memoria local: héroe, pionero, trabajador incansable y padre fundador de una comunidad armónica. Sin embargo, la figura del inmigrante que es legitimada en los lugares de memoria, en las prácticas conmemorativas y en los objetos mnemónicos analizados, no es la de cualquier inmigrante, sino la del inmigrante europeo, exitosamente integrado a la cultura nativa y respetuoso de las instituciones locales. Ese proceso no solo invisibiliza la presencia de inmigrantes de otros orígenes en la historia de Berisso, sino que, además, silencia/olvida los aspectos dolorosos o conflictivos vividos por los propios inmigrantes europeos en esta ciudad.

Antes de cerrar el texto quisiéramos dejar planteado, para futuros trabajos, un eje de análisis que se desprende de este artículo y no hemos podido abordar. El mismo refiere a cierta mirada "global» $u$ "holista» sobre el vínculo entre inmigración y memoria oficial que atraviesa algunos pasajes del texto. Si bien los lugares de memoria, las prácticas conmemorativas y los objetos analizados han sido claramente delimitados y hemos indicado las fechas en que fueron colocados los bustos y las placas, entendemos que cada una de ellas merecería un artículo en si mismo para reconstruir cronológicamente su historicidad y, así, poder analizar la existencia de ciclos memoriales y su vínculo con las políticas de memoria implementadas a nivel local (Besse, 2012). 


\section{BIBLIOGRAFÍA}

Alegría, L. (2012). Patrimonio, museos y museología. En D. Marzal (Comp.), Hecho en Chile. Reflexiones en torno al patrimonio cultural (pp. 145-172). Santiago: Andros Impresores.

Anderson, B. (2007). Comunidades imaginadas. Reflexiones sobre el origen y la difusión del nacionalismo. Ciudad de México: Fondo de Cultura Económica.

Ansaldi, W. (1996). Las prácticas sociales de la conmemoración en la Córdoba de la modernización, 1880-1914. Sociedad, 8, 95-127.

Assmann, J. (2010). Communicative and Cultural Memory. En A. Erll y A. Nunning (Eds.), A Companion to Cultural Memory Studies (pp. 109-118). Berlin/New York: Walter de Gruyter.

Barfield, T. (2000). Diccionario de Antropología. Ciudad de México: Siglo XXI.

Baczko, B. (2005). Los imaginarios sociales. Buenos Aires: Nueva Visión.

Besse, J. (2012). Entre dos muertes. Escansiones y silencios en las primeras narraciones historiográficas acerca del 16 de junio de 1955. Revista Memória em Rede, 2(7), 1-21.

Bjerg, M. (2016). La inmigración en la Argentina: un mito fundacional y un problema historiográfico. Revista Electrónica de Fuentes y Archivos, 7(7), 322-329.

Bjerg, M. (2019). El cuaderno azul, el perro de peluche y la flor de trencadis. Una reflexión sobre la cultura material, las emociones y la migración. Pasado Abierto, 9, 140-157.

Bustamante, J. (2016). Voces de los objetos. Encrucijadas y desafíos en contextos de memoria y conmemoración. Antropologías del Sur, 3(5), 15-32.

Bretal, E. (2016). La Edad de Oro en las representaciones de ex-obreros del frigorífico Swift de Berisso. Trabajo y Sociedad, 27, 291-304.

Cattaruzza, M.A. (2007). Los usos del pasado. La historia y la política argentinas en discusión, 1910-1945. Buenos Aires: Editorial Sudamericana.

Ceva, M. (2005). La construcción de una memoria familiar en la inmigración biellesa, 18951960. Estudios Migratorios Latinoamericanos, 19(58), 461-482.

Connerton, P. (1993). Como as sociedades recordam. Lisboa: Oerias.

Da Orden, M. (2004). Fotografía e identidad familiar en la migración masiva a la Argentina. Historia Social, 48, 3-25.

Da Orden, M. (2010). Una familia y un océano de por medio. La emigración gallega a la Argentina: una historia a través de la memoria epistolar. Barcelona: Anthropos.

Devoto, F. (2009). Historia de la inmigración en Argentina. Buenos Aires: Sudamericana.

De Cristóforis, N. (2016). Inmigrantes y colonos en la provincia de Buenos Aires: una mirada de largo plazo (siglos XIX-XXI). Buenos Aires: Universidad de Buenos Aires.

Eiss, P. (2002). Redemption Archives. Remembering the Future in a Revolutionary Past. Comparative Studies in Society and History, 44(1), 106-136.

Franco, M., y Levín, F. (Comps.) (2007). Historia Reciente. Perspectivas y desafíos para un campo en construcción. Buenos Aires: Paidós. 
Garguin, E. (2009). "Los argentinos descendemos de los barcos». Articulación racial de la identidad de clase media en Argentina (1920-1960). En S.E. Visacovsky y E. Garguin (Comps.), Moralidades, economías e identidades de clase media: estudios históricos y etnográficos (pp. 61-94). Buenos Aires: Antropofagia.

GEMAS (2016). Prólogo. En A.M. Ramos, C. Crespo y M.A. Tozzini (Comps.), Memorias en lucha: recuerdos y silencios en contextos de subordinación y alteridad (pp. 9-13). Viedma: Universidad Nacional de Río Negro.

Gillis, J.R. (1994). Conmemorations. The Politics of National Identity. New Jersey: Princeton University Press.

Glynn, I., y Kleist, J.O. (2012). The Memory and Migration Nexus: An Overview. En I. Glynn y J.O. Kleist (Eds.), Memory and Migration: Perceptions of the Past and the Politics of Incorporation (pp. 3-32). Londres: Palgrave Macmillan.

Glynn, I., y Kleist, J.O. (2015). Memory Studies and Migration Studies at the Crossroads: an AngloSaxon Perspective. En M. Baussant, I. Dos Santos, É. Ribert e I. Rivoal (Eds.), Migrations humaines et mises en récit mémorielles (pp. 37-58). Paris: Universitaires de Paris Ouest.

Guruciaga, L. (1995). Berisso. Fotomemoria. Buenos Aires: Nueva Librería.

Herrera, N. (2018). Inmigración, política y memoria: La Fiesta Provincial del Inmigrante (Berisso, 1978-2015): un ritual conmemorativo a través del cual la comunidad se imagina a sí misma (tesis doctoral inédita). La Plata, Universidad Nacional de La Plata.

Herrera, N. (2019). Entre memorias oficiales e identidades colectivas: la Fiesta Provincial del Inmigrante (Berisso, Argentina, 2010-2015). Amnis Revue d'etudes des sociétés et cultures contemporaines Europe-Amérique, 18, https://doi.org/10.4000/amnis.4137

Herrera, N., y Monkevicius, P. (2019). La memoria social en los estudios migratorios: Genealogía e intersecciones disciplinarias. III Jornadas de Migraciones Cartografias en movimiento: memorias, violencias y resistencias. José Clemente Paz: UNPAZ.

Huyssen, A. (2001). En busca del futuro perdido. Cultura y memoria en tiempos de globalización. Ciudad de México: Fondo de Cultura Económica.

Huyssen, A. (2003). Diaspora and Nation: Migration into Other Pasts. New German Critique, 88, 147-164.

lucci, M.J. (2012). La producción y reproducción de imaginarios urbanos por parte de las autoridades municipales. Revista Pilquen, XIV(15), 1-15.

James, D. (2004). Doña María. Historia de vida, memoria e identidad política. Buenos Aires: Manantial.

James, D., y Wolfson, L. (1987). 17 y 18 de octubre de 1945: el peronismo, la protesta de masas y la clase obrera Argentina. Desarrollo Económico, 27(107), 445-461.

Jelin, E. (2002). Los trabajos de la memoria. Madrid: Siglo XXI Editores.

Jelin, E., y Langland, V. (2003) (Comps.). Monumentos, memoriales y marcas territoriales. Madrid y Buenos Aires: Siglo XXI.

König, M., y Ohliger, R. (2006). Facing Migration History in Europe Between Oblivion and Representation. En Enlarging European Memory (pp. 11-19). Ostfildern: Jan Thorbecke Verlag. 
Lafont-Couturier, H. (2007). El museo nacional de historia de la inmigración: un museo sin colecciones. Museum International. Patrimonio de los inmigrantes, LIV(1-2), 40-46.

Lefebvre, H. (1971). De lo rural a lo urbano. Barcelona: Ediciones Península.

Lobato, M.Z. (2004). La vida en las fábricas. Trabajo, protesta y política en una comunicad obrera, Berisso (1904-1970). Buenos Aires: Prometeo.

Maier, C.S. (1993). A Surfeit of Memory? Reflections on History, Melancholy and Denial. History and Memory, 5, 136-152.

Messina, L. (2011). El ex Parque clandestino de detención "Olimpo" como dispositivo de memoria: reflexiones sobre las marcas territoriales y sus usos. Aletheia, 2(3), 1-26.

Messina, L. (2019). Lugares y políticas de la memoria. Notas teórico-metodológicas a partir de la experiencia argentina. Kamchatka. Revista de análisis cultural, 13, 59-77.

Míguez, E. (1992). Tensiones de identidad: Reflexiones sobre la experiencia italiana en la Argentina. En F. Devoto y E. Míguez (Comps.), Asociacionismo, trabajo e identidad étnica. Los italianos en América Latina en una perspectiva comparada (pp. 333-358). Buenos Aires: CEMLA/ISER/IEHS.

Mostov, J. (2000). Sexing the Nation/Desexing the Body. Politics of National Identity in the Former Yogoslavia. En T. Mayer (Comp.), Gender Ironies of Nationalism. Sexing the Nation (pp. 89-110). Londres-Nueva York: Routledge.

Muñiz Terra, L. (2012). Los (ex) Trabajadores de YPF. Trayectorias laborales a veinte años de la privatización. Buenos Aires: Espacio Editorial.

Noiriel, G. (1996). The French Melting Pot: Immigration, Citizenship and National Identity. Minneapolis: University of Minnesota Press.

Nora, P. (2008). Les lieux de mémoire. Montevideo: Trilce.

Olick, J. (2003). Whats Does It Mean to Normalize the Past? Official Memory in German Politics since 1989. En States of Memory. Continuities, Conflicts, and Transformations in National Retrospection (pp. 259-288). Durham: Duke University Press.

Pollak, M. (2006). Memoria, olvido, silencio. La producción social de identidades frente a situaciones limite. La Plata: Ediciones Al Margen.

Pontes, V. (2016). Los museos de la inmigración como modelo para la musealizacion del patrimonio inmaterial. Cuadernos de Arte de la Universidad de Granada, 47, 115-130.

Rousso, H. (1987). Le Syndrome de Vichy. París: Seuil

Segato, R.L. (2007). La nación y sus otros: raza, etnicidad y diversidad religiosa en tiempos de políticas de la identidad. Buenos Aires: Prometeo.

Todorov, T. (2000). Los abusos de la memoria. Barcelona: Paidós.

Tošić, J., y Palmberger, M. (2016). Introduction: Memories on the Move. Experiencing Mobility, Rethinking the Past. En M. Palmberger y J. Tošić (Eds.), Memories on the Move. Experiencing Mobility, Rethinking the Past (pp. 1-16). Londres: Palgrave Macmillan.

Wieviorka, A. (1998). L'Ére du témoin. París: Plon. 